\title{
СИСТЕМА ПОДГОТОВКИ ПСИХОЛОГОВ В СФЕРЕ УПРАВЛЕНИЯ ПЕРСОНАЛОМ В МОСКОВСКОМ ГУМАНИТАРНОМ УНИВЕРСИТЕТЕ
}

\author{
Е. С. Балабанова \\ Московский гуманитарный университет
}

Аннотация: В статье представлены основные направления и содержание учебнометодической и научно-методической работы кафедры социальной и этнической психологии Московского гуманитарного университета по подготовке психологов в сфере управления персоналом.

Ключевые слова: психология управления; психолог; магистр; магистратура; Московский гуманитарный университет; управление персоналом

\section{THE SYSTEM OF TRAINING PSYCHOLOGISTS IN THE FIELD OF PERSONNEL MANAGEMENT AT MOSCOW UNIVERSITY FOR THE HUMANITIES}

\author{
E. S. Balabanova \\ Moscow University for the Humanities
}

\begin{abstract}
The paper presents the main directions and contentofacademic and methodological work on training psychologists in the field of personnel management at the Department of Social and Ethnic Psychology of Moscow University for the Humanities.

Keywords: managerial psychology; psychologist; master's degree; graduate study; Moscow University for the Humanities; personnel management

Сложившиеся социально-экономические условия в России, их нестабильность и сопутствующие кризисы, ориентируют менеджмент на максимальное использование кадрового потенциала организации в целях сохранения организационной эффективности и успешности бизнеса.

Возрастание у руководителей организаций интереса к персоналу, прежде всего, к его качеству, наблюдалось с конца 90-х годов XX века. Данная тенденция выступила основанием для привлечения в сферы управления и бизнеса специалистов с психологическими знаниями. Также эти обстоятельства подтолкнули вузы к расширению программ подготовки профессионалов по управлению человеческими ресурсами, в задачи которых входило бы посторенние научно обоснованной системы работы с персоналом с опорой на знания в области психологии управления.

Психология управления стала обязательной дисциплиной многих специальностей, связанных с организационным и финансовым менеджментом. Она вооружала специалистов по работе с персоналом эффективными управленческими
\end{abstract}


методами, которые позволяли создавать благоприятные условия для максимального развития человеческого потенциала, что, в свою очередь, способствовало развитию организации в целом. Для комплексного решения задач, связанных с психологическим обеспечением работы с кадровым составом организации, на психологических факультетах многих вузов выделилась отдельная специализация «Психология управления персоналом», обеспечивающая им необходимую подготовку.

В 2000-м году в Московском гуманитарном университете (МосГУ, тогда Московская гуманитарно-социальная академия) была организована подготовка психологов в сфере управления персоналом на кафедре социальной и этнической психологии. Кафедра была организована в1994 г., возглавлял ее Анатолий Лактионович Журавлев, в то время - кандидат психологических наук, научный сотрудник Института психологии Российской академии наук. В настоящее время Анатолий Лактионович Журавлев - доктор психологических наук, профессор, академик Российской академии наук и Российской академии образования, научный руководитель Института психологии РАН, научный руководитель факультета психологи, педагогики и социологии МосГУ. Разработкой концепции специализации, содержательным наполнением дисциплин, подбором преподавателей, организацией учебного процесса занимались под его руководством два заместителя: по научной работе - доцент 0. В. Лунева и по учебной работе - доцент Е. С. Соколова (Балабанова). В этой работе им помогали все преподаватели и сотрудники кафедры: В. П. Позняков, В. П. Левкович, Е. П. Резников, А. А. Обознов, В. А. Хащенко, А. Б. Купрейченко, М. В. Муконина, П. А. Гариева, Е. Н. Смирнова, Л. М. Рудина, Н. Н. Будрейка.

Качество образовательного процесса определялось активным взаимодействием кафедры с Институтом психологии РАН и Московским государственным университетом им. М. В. Ломоносова. А. Л. Журавлеву удалось сформировать профессиональный коллектив кафедры, который под его руководством успешно решал и решает сейчас учебные и научно-исследовательские задачи.

Высокий уровень подготовки студентов обеспечивался путем привлечения к разработке и чтению учебных курсов опытных и талантливых преподавателей, использующих современные образовательные технологии и совмещающих учебно-методическую деятельность с научной. Особое внимание уделялось сотрудничеству с практикующими специалистами, работающими в тренинговых и консалтинговых компаниях, службах персонала, имеющих большой опыт применения социально-психологических знаний в организационном консультировании и проведении бизнес-тренингов. В разное время на кафедре работали кандидаты и доктора психологических наук Т. С. Кабаченко, О. Г. Носкова, Л. Г. Дикая, Е. Д. Дорофеев, А. Н. Занковский, С. Е. Поддубный, А. И. Магура, А. А. Вахин, О. В. Вихристюк, Т. А. Нестик, А. Н. Татарко и др. Большой интерес у студентов вызывали тренинги и мастер-классы О. В. Луневой и Л. М. Рудиной, направленные на подготовку тренеров и имидж-консультантов руководителей.

Специализация «Психология управления персоналом» пользовалась большой популярностью у студентов. Набор на специализацию осуществлялся на конкурсной основе. Подготовка по специализации носила междисциплинарный 
характер и опиралась на имеющуюся у студентов теоретическую базу, сформированную при освоении фундаментальных психологических дисциплин. Также она предусматривала интенсивную практическую подготовку с использованием активных форм и методов обучения. Конкурентоспособность выпускников обеспечивали широкие возможности баз производственной практики. Студенты, проходившие практику в службах персонала крупных компаний «Сбербанк России», «Газпром», «Лэтуаль», «Трансаэро» и др., получали незаменимый опыт профессиональной деятельности и могли ориентироваться в широком круге вопросов работы с персоналом организации. Кафедра получала благодарности от руководителей этих компаний за качество подготовки студентов, а лучшие студенты престижную работу.

Структура и содержание специализации были разработаны на основе следующих исходных положений: соответствие содержания учебных дисциплин основным направлениям работы психолога с персоналом; универсальный характер подготовки, позволяющий выпускникам ориентироваться в различных сферах деятельности, связанных с учётом человеческого фактора; соответствие запросам современного рынка труда и повышение конкурентоспособности выпускников.

В соответствии с решением образовательных задач дисциплины специализации объединялись в обучающие модули. Первый модуль составили дисциплины, обеспечивающие общую профессиональную подготовку психолога по управлению персоналом: «История зарубежной и отечественной психологии персоналом», «Организационная психология», «Современные проблемы психологии управления персоналом», «Психологические основы профориентации и профконсультирования», «Кросскультурная психология персонала», «Конфликты в организациях», «Психология рекламы и маркетинга в организации», «Индивидуальный стиль саморегуляции деятельности».

Во второй модуль вошли дисциплины, формирующие системные знания и умения в работе с персоналом организации: «Система управления персоналом организации», «Планирование карьеры», «Формы обучения персонала», «Система оценки персонала», «Современные технологии подбора персонала», «Перцептивная диагностика персонала», «Психология совместимости и комплектования производственных групп», «Групповые формы работы с персоналом», «Адаптация и стимулирование персонала», «Психологические основы мотивации персонала».

Третий модуль составили дисциплины, направленные на подготовку психолога для решения задач, связанных с воздействием на персонал, и формирующих профессиональную компетентность психолога-практика: «Организационно-управленческое консультирование», «Психологические основы организации переговоров», «Психология эмоциональных состояний персонала», «Психологические основы корпоративной культуры», «Коммуникативный видеотренинг», Психология формирования имиджа», «Психологические основы PR в организации», «Психология воздействия».

В целом совокупность дисциплин специализации отражала основные направления работы психолога в организации: определение потребности в персонале, анализ рынка труда, привлечение и поиск кандидатов на должность, разработка и реализация систем оценки и мотивации персонала, определение потребности в 
обучении персонала и разработка программ обучения и развития персонала, планирование карьеры работников организации, формирование кадрового резерва, психологическое обеспечение организационных коммуникаций, диагностика персонала и трудовых групп, выявление психологических проблем, их анализ и проектирование вариантов их решения, а также - практическая психологическая работа с руководством, сотрудниками и производственными коллективами.

В период 2000-2013 гг. подготовку по специализации «Психология управления персоналом» получили около 1000 выпускников, которые успешно устраивались на работу или повышали свой профессиональный статус в той организации, где работали до получения образования.

Значительное количество выпускников, прошедших обучение по специализации «Психология управления персоналом», и сейчас работает по специальности в службах персонала, кадровых агентствах, образовательных и консультативных структурах разного уровня в государственных и коммерческих организациях. Полученное образование позволяет выпускникам создавать собственные тренинговые компании, психологические консультативные центры, либо работать в различных проектах в качестве приглашенного психолога. Психологическая подготовка создавала базу карьерного роста выпускников и развития не только в области психологии, но и менеджмента. Владение психологической составляющей в управленческой деятельности усиливало их позиции в организациях, помогало делать успешной любую профессиональную деятельность, связанную с человеческими взаимоотношениями. Среди выпускников специализации были те, кто продолжили обучение в аспирантуре по кафедре социальной и этнической психологии, защитили кандидатские диссертации и, профессионально преуспев, пришли на кафедру преподавателями. Так, совмещая успешную практическую деятельность с преподавательской работой, передавали свой опыт новому поколению специалистов Е. С. Никулина, Е. Н. Молодых, Д. П. Веселовский, Е. А. Груздева и др.

С переходом на уровневую систему образования подготовка психологов для работы с персоналом организации стала реализоваться в рамках магистерской программы «Социальная и организационная психология». Основой подготовки магистров психологии по данной программе являлось сочетание передовых научных идей и научно-методологических подходов к социальной и организационной психологии, взаимосвязь фундаментальных знаний с их научно-практическим применением.

Структура и содержание магистерской программы «Социальная и организационная психология» были разработаны доктором психологических наук, профессором кафедры социальной и этнической психологии Владимиром Петровичем Позняковым, осуществлявшим научное руководство программой до 2013 г.

Базовую часть учебного плана составляли дисциплины, направленные на усвоение магистрантами знаний фундаментальной и прикладной социальной и организационной психологии, формирование навыков научно-исследовательской деятельности: «Теоретические подходы к социальной психологии», «Психология социального познания», «Психология предпринимательства», «Гендерная социальная психология», «Психология массовых коммуникаций», «Психология управленческого взаимодействия», «Социальная психология труда, занятости и 
безработицы», «Психология воздействия», «Современные методы социальной психологии». Дисциплины вариативной части были направлены на развитие компетенций в области практической реализации полученных знаний: «Психология организации переговоров», «Психологические основы профориентации и профконсультирования», «Современные технологии подбора персонала», «Деловые коммуникации: анализ и методы оптимизации», «Управление конфликтами в организации», «Диагностика и развитие организационной культуры», «Система оценки персонала организации».

Дальнейшее развитие магистерская программа получила с приходом на кафедру социальной и этнической психологии доктора психологических наук, профессора Александра Алексеевича Грачева, который оставался руководителем программы подготовки магистров до 2017 г. В данный период отличительной особенностью программы магистратуры стала ориентация ее содержания на разные виды практической деятельности психолога в организации, а также взаимосвязь с научным направлением, разрабатываемым кафедрой социальной и этнической психологии «Личность и группа в изменяющихся социально-экономических условиях». Так, в учебный план были введены актуальные практико-ориентированные курсы «Организационный тренинг», «Психологическая служба в организации», «Коуч-консалтинг» и теоретико-методологические учебные дисциплины «Социальная психология личности и группы в изменяющемся обществе», «Современные методы исследования в социальной и организационной психологии» и «Отрасли, психологии, психологические практики и психологические службы», направляющих обучающихся к соответствующей исследовательской проблематике.

Сегодня кафедра социальной и этнической психологии обратилась к своему многолетнему опыту подготовки психологов для работы с персоналом организации и использует его в образовательной программе магистратуры «Психология управления персоналом», продолжая формировать учебно-методические и научно- исследовательские традиции в данном направлении. Руководит научным содержанием магистерской программы профессор кафедры социальной и этнической психологии Ольга Викторовна Лунева, кандидат психологических наук, доцент. Ольга Викторовна стояла у истоков формирования системы подготовки психологов по управлению персоналом, она имеет опыт работы психологом на промышленных предприятиях, является известным специалистом по изучению групповой динамики и проведению бизнес-тренингов.

В современных условиях программа магистратуры ориентирована, вопервых, на получение знаний по психологии управления персоналом на основе современного состояния социальной и организационной психологии. Вовторых, - на развитие компетенций в области реализации полученных знаний в практической, организационно-управленческой и проектно-инновационной сферах профессиональной деятельности психолога, а также в научно-исследовательской работе. Данный подход позволяет сформировать у выпускников систему общекультурных, общепрофессиональных и профессиональных компетенций для решения комплексных задач в области психологии управления в различных сферах человеческой деятельности, а также в сферах межличностных и социальных взаимодействий в организации. 
Учебные дисциплины программы магистерской подготовки разделены на три группы, которые направлены на формирование компетенций в разных видах профессиональной деятельности психолога в организации. Первая группа объединяет дисциплины базовой подготовки магистров психологии, направленные на углубление знаний и развитие навыков научно-исследовательской деятельности: «Планирование теоретического и эмпирического исследования», «Актуальные проблемы теории и практики современной психологии», «Научные школы и теории современной психологии», «Статистические методы в психологии». Особое внимание в процессе обучения магистрантов в рамках программы «Психология управления персоналом» уделяется дисциплинам «Социальная психология личности и группы в изменяющихся условиях», Современные методы исследования в социальной и организационной психологии», «Организационная психология», «Психология управления персоналом». Их теоретическое содержание направлено на формирование готовности к постановке исследовательских задач в области психологического сопровождения организационных и производственных процессов, без понимания которых невозможно эффективное управление организацией в современных условиях.

В процессе исследовательской деятельности магистрантами также разрабатывается научная проблематика кафедры, связанная с исследованием социально-психологических проблем трудовой деятельности в современных организациях. Предметами исследования в магистерских диссертациях являются такие социально-психологические феномены, как социальный интеллект и коммуникативные ориентации персонала, психологическая готовность к деловой активности и отношение к работе, стрессоустойчивость, психологическое благополучие персонала и т. п.

Содержание дисциплин второй группы направлено на развитие умений и навыков в практической деятельности психолога (диагностика персонала, овладение техниками и методами оценки персонала, планирования карьеры, управление групповой динамикой). Эти задачи решаются через освоение дисциплин «Психология управления персоналом», «Система оценки персонала организации», «Психодиагностике и развитие рабочих групп», «Психология управления карьерой», «Коуч-консалтинг», «Организационный тренинг», «Мотивирование персонала». Ряд учебных дисциплин данной группы - «Профессиональное самоопределение», «Психологическая служба в организации», «Организационноуправленческое консультирование», «Диагностика и развитие организационной культуры» - направлен на решение социально-психологических задач в организации, таких как формирование благоприятного социально-психологического климата, повышение организационной приверженности персонала, обеспечение процессов профессиональной социализации и адаптации, раскрытие индивидуальности и потенциала работников.

В данную группу включены учебные дисциплины, формирующие навыки выстраивания системы эффективных профессиональных коммуникаций на основе современных требований организационной среды «Иностранный язык в профессиональной сфере», «Видеотренинг «Деловые коммуникации», «Технологии презентации научных проектов», «Управление конфликтами в организации», 
«Психология переговоров».

Содержание учебных дисциплин третьей группы, в которую входят «Психология экономического поведения», «Психология предпринимательства» и «Психология рекламы и PR в организации», формирует необходимые компетенции психолога в организационно-управленческой и проектной-инновационной сферах профессиональной деятельности.

В преподавании учебных дисциплин магистерской программы «Психология управления персоналом» используются инновационные методы обучения, интерактивные и тренинговые формы, работа с кейсами, технологии организационного проектирования. Подготовка строится на активных социально-психологических методах обучения, которые направлены на развитие навыков эффективных управленческих коммуникаций и взаимодействий, умений по формированию благоприятного климата и системы межличностных отношений в трудовом коллективе, актуальной организационной культуры и ценностного единства сотрудников. Учебный процесс проходит в специализированных кабинетах и лабораториях, в числе которых кабинет консультирования (активные методы подготовки), лаборатория профессиональных коммуникаций, научно-методическая лаборатория.

Содержание и структура образовательной программы «Психология управления персоналом» отражают передовые подходы к подготовке магистров психологии и направлены на повышение их профессионального статуса и расширение возможностей профессиональной самореализации в практической, организационно-управленческой, проектно-инновационной и научно-исследовательской сферах профессиональной деятельности (Приказ Минобрнауки ... , Электр. ресурс).

Содержание учебных дисциплин разработано докторами наук А. А. Грачевым, В. П. Позняковым, Т. П. Емельяновой и кандидатами наук О. В. Луневой, Е. С. Балабановой, Е. Б. Редькиной, которые ведут в соответствующих научных областях психологии научно-исследовательскую и научно-практическую работу. Экспертами содержания учебных дисциплин, а также преподавателями практических курсов выступают представители профессионального сообщества, практикующие в сфере управления персоналом. Взаимодействие с реально работающими представителями профессии расширяет научно-образовательное пространство, создаваемое кафедрой социальной и этнической психологии, обеспечивает формирование профессионального самосознания и требуемых компетенций выпускников, способствует успешному трудоустройству выпускников и реализации их заинтересованности в профессиональном развитии и карьерном росте.

\section{СПИСОК ЛИТЕРАТУРЫ}

Приказ Минобрнауки России от 23.09.2015 N 1043 «Об утверждении федерального государственного образовательного стандарта высшего образования по направлению подготовки 37.04.01 Психология (уровень магистратуры)» (Зарегистрировано в Минюсте России 12.10.2015 N 39285) [Электронный ресурс] // Справочная правовая система «КонсультантПлюс» URL: http://www.consultant.ru/ document/cons_doc_LAW_187579/ (дата обращения: 20.02.2018). 
Балабанова Екатерина Светославовна - кандидат психологических наук, доцент, доцент кафедры социальной и этнической психологии Московского гуманитарного университета. Адрес: 111395, Россия г. Москва, ул. Юности, д. 5. Тел.: +7(499) 374-56-11. Эл. адрес: ebalabanova@mosgu.ru

Balabanova Ekaterina Svetoslavovna, Candidate of Psychology, Associate Professor, Associate Professor, Department of Social and Ethnic Psychology, Moscow University for the Humanities. Postal address: 5, Yunosti St., Moscow, Russian Federation, 111395. Tel.: +7(499) 374-56-11. E-mail: ebalabanova@mosgu.ru

\section{Для цитирования:}

Балабанова Е. С. Система подготовки психологов в сфере управления персоналом в Московском гуманитарном университете [Электронный ресурс] // Научные труды Московского гуманитарного университета. 2018. № 1. URL: http://journals.mosgu.ru/trudy/ article/view/678 (дата обращения: дд.мм.гг.). DOI: 10.17805/trudy.2018.1.3 